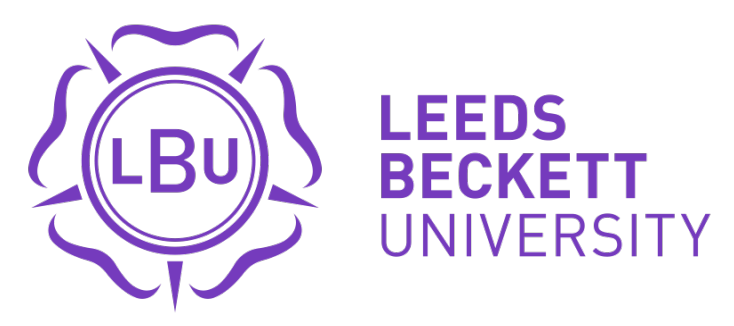

Citation:

Nunn, A (2014) The contested and contingent outcomes of Thatcherism in the UK. Capital and Class, 38 (2). 303 - 321. ISSN 0309-8168 DOI: https://doi.org/10.1177/0309816814530126

Link to Leeds Beckett Repository record:

https://eprints.leedsbeckett.ac.uk/id/eprint/230/

Document Version:

Article (Accepted Version)

The aim of the Leeds Beckett Repository is to provide open access to our research, as required by funder policies and permitted by publishers and copyright law.

The Leeds Beckett repository holds a wide range of publications, each of which has been checked for copyright and the relevant embargo period has been applied by the Research Services team.

We operate on a standard take-down policy. If you are the author or publisher of an output and you would like it removed from the repository, please contact us and we will investigate on a case-by-case basis.

Each thesis in the repository has been cleared where necessary by the author for third party copyright. If you would like a thesis to be removed from the repository or believe there is an issue with copyright, please contact us on openaccess@leedsbeckett.ac.uk and we will investigate on a case-by-case basis. 


\title{
The Contested and Contingent Outcomes of Thatcherism in the
} $\mathrm{UK}^{1}$

\begin{abstract}
"Thatcherism... should be judged in terms of its success or failure in disorganising the labour movement and progressive forces, in shifting the terms of political debate, in reorganising the political terrain and in changing the balance of forces in favour of capital and the right" Hall and Jacques, (1983: 13).
\end{abstract}

\begin{abstract}
The death of Margaret Thatcher in April 2013 sparked a range of discussions and debates about the significance of her period in office and the political project to which she gave her name: Thatcherism. This article argues that Thatcherism is best understood as a symbolically important part of the emergence of first-phase neo-liberalism. It engages with contemporary debates about Thatcherism among Marxist commentators and suggests that several apparently divergent positions can help us now reach a more useful analysis of Thatcherism's short and long-term outcomes for British political economy. The outcomes identified include: An initial crisis in the neo-liberal project in the UK; the transformation of the party political system to be reflective of the politics of neo-liberalism rather than its contestation; long-term attempts at the inculcation of the neo-liberal individual; de-industrialisation and financial sector dependence and a fractured and partially unconscious working class. In all longterm outcomes the contribution of Thatcherism is best understood as partial and largely negative; in clearing the ground for a longer-term and more constructive attempt to embed neo-liberal political economy. It is suggested that this analysis can inform current debates on the left of British politics about how to oppose and challenge the imposition of neo-liberal discipline today.
\end{abstract}

\section{Introduction}

The death of Margaret Thatcher in April 2013 marked something of a symbolic milestone for British politics and political economy. Thatcher is held up by supporters as the agent of transformation of the British state into a modern flexible economy. To her detractors she is a figure of hatred, blamed for multitudinous and damaging effects on politics, society and the lives of many - especially poor people. This article reflects on Thatcher's legacy through the ruling ideology that her period in office spawned: Thatcherism.

While Rogers' contribution to this volume looks back to identify trends in political economy that are commonly associated with Thatcherism, but can arguably said to have longer roots; this paper looks beyond Thatcher's time in office to show the longer running effects on British politics and political economy. The paper traces five prominent outcomes of Thatcherism in the UK: (1) a crisis in the neo-liberal project; (2) the transformation of party competition such that all mainstream parties are avowedly neo-liberal in orientation; (3) the inculcation of the neo-liberal individual; (4) deindustrialisation and financial sector dependence and (5) the fractured and unconscious working class.

1 This paper was previously given as a talk at the Transpennine Working Group (http://csetranspennine.wordpress.com/) of the CSE Symposium on Thatcherism in Manchester in April 2013 and at Leeds Taking Soundings (http://www.takingsoundings.org.uk/) in May 2013. I am grateful for the comments, suggestions and queries of participants at these events. I am also grateful for comments from Colin Webster, Jamie Morgan and Dave Robertshaw and two anonymous referees which considerably strengthened the argument. 
The purpose of identifying these outcomes is that, at the very least, the various attempts underway to unite against contemporary manifestations of capitalist hegemony need to take these into account in the British context. This is important because challenging these legacies would need to be part of any emergent political, economic and social alternative to neo-liberalism. At a time of crisis when the possibilities of such alternatives emerge, it is perhaps useful to look back in this way to understand the roots and constraints of the current political conjuncture. ${ }^{\text {ii }}$

The paper starts by questioning and qualifying (rather than rejecting outright) the idea that Thatcher was as potent a political agent as popular sentiment might have it. It then goes on to interrogate the meaning and definition of Thatcherism before moving into an analysis of the one short- and four longterm outcomes from Thatcherism. In each, it is concluded that Thatcherism's direct outcome was largely limited to the destruction of pre-existing social and institutional structures. In particular this was focused on the deconstruction of the social, economic and political structures of working class power. However, Thatcherism was much less successful at articulating a new accumulation, governmental or ideological regime capable of sustaining the neo-liberal project that it sought to promote. The problems associated with this were bound up in a short-term crisis in accumulation, legitimacy and social reproduction associated with Thatcherism. Indeed, in attempting to resolve these crisis tendencies, while distancing itself rhetorically from the confrontational politics associated with Thatcherism, New Labour perhaps did more than Thatcher's governments to advance the neoliberal project. The final section sketches out some of the implications of this analysis for left strategy today.

\section{What is/was 'Thatcherism'?}

For some, despite the widespread use of the term, Thatcherism never was anything distinctive (for e.g. see Schwarz 1987). For others it required careful political, social and economic analysis. In an influential account, Andrew Gamble (1988) saw Thatcherism as the alliance of free market economics with the strong state discipline that was needed to impose property rights, stable money and to counter special interests such as trade unions. For Stuart Hall (1983), Thatcherism was a political process of narrating the troubles facing the British economy and society in the 1970s in a way that gave rise to popular support for Thatcher's reforming and authoritarian government. For Hall the success of Thatcherism was in shifting the terrain on which class struggle unfolds to the right. Jessop et al. (1984) took issue with this interpretation, claiming it presented Thatcherism, its supporting coalition and ideological predominance as overly potent. Instead, they drew attention to the contradictions and weaknesses in Thatcherism. They argued that Thatcherism represented a 'two-nations' attempt to divide the working class between those who would benefit from popular asset ownership, right to buy (council housing) and new service sector job growth and those that would be negatively affected by de-industrialisation, public sector spending cuts and increased market discipline. They also suggested that economic weaknesses resulted from the failure to be able to identify a specific national economic project (or accumulation strategy), a problem grounded in the internationalization of British capital (Radice 1984).

Despite the slightly terse debate (Jessop et al. 1984; Hall 1985; Jessop et al. 1985) between Hall and Jessop et al. the terms of their shared analysis provides a useful yardstick by which to analyse Thatcherism's long-term outcomes. Both stressed the background to Thatcherism as a multi-faceted crisis in post-war social democracy. Both also stressed the importance of the shifting ideological ground of British politics, but despite this the failure of Thatcherism to propose a full - hegemonic solution to the problems of the collapse of social democracy (for e.g. see Hall 1985: 120). The 
discussion below offers an interpretation of the long-term outcomes of Thatcherism that focusses on the extent to which it laid the ground for subsequent developments that attempted to confront the economic, social and ideological weakness in the neo-liberal project it left behind. Those attempts though would be undertaken on a political terrain that had shifted decisively in support of neoliberalism in relation to party politics, class politics and consciousness.

It is therefore useful to identify Thatcherism's contribution to the wider programme of neo-liberal reform, though this too is often an ambiguous concept (Boas and Gans-Morse 2009) ) $^{\mathrm{iii}}$. Overall, following the likes of Harvey (2005; 2010) and Cammack (2002), neo-liberalism can be defined as a class project to (a) restore the ascendency of capitalist class power over labour after a period during which labour had made substantial relative gains and (b) to promote financial capital over other capitalist interests.

As Harvey (2010: Ch1) notes, neo-liberal political projects have employed a number of different strategies including off-shoring, increasing competition among labour through increased migration and the development of new labour saving technologies such as automation. In this context, one necessary, but not sufficient, part of what Thatcherism means is a specifically state-led project to advance neo-liberalism as distinct (but nevertheless associated with) the private strategies adopted separately and as a class by capitalists themselves (such as shifting production to cheaper wage locations, investing in labour saving technology, switching operations to financial activities).

To understand the next part of what Thatcherism means it is necessary to think of neo-liberalism as having two distinct aspects: variously referred to as first/second phase; roll-back/roll-out (Peck and Tickell 2002; Nunn 2005; Craig and Cotterell 2007; Nunn 2007). Here 'roll-back' or 'first-phase' restructuring refers to the destruction of the social and institutional structures of post-war social democracy. Essentially, these types of reforms are a prime example of what Polanyi (1957) described as the extension of market discipline. By contrast, second-phase strategies can be associated with attempts to contain the negative effects of market discipline in ways that can sustain it. This is analogous to the second part of Polanyi's 'double movement' or socialisation.

Thatcherism can thus be understood as principally oriented around the extension of market discipline in a decisive intervention in the pre-existing tensions in post-war class relations to fundamentally weaken the position of the working class. This was embodied in the adoption of monetarism, public expenditure cuts, privatisation, attacks on the position of (especially organised) labour and openness to the international economy in place of a preference for sheltering labour markets and prices in the post-war Keynesian style (Gamble 1989: 352-6; Jessop 2003: 139-40). Indeed, when discussing this two-phase description of neoliberalism, it is easy use 'Thatcherism' (or 'Reaganomics') as a short-cut semantic descriptor for first-phase strategies. ${ }^{\text {iv }}$

Without rejecting outright the idea that Thatcher was a very significant post-war politician, the neoliberal revolution in the UK had started before her (as Rogers' contribution to this volume demonstrates) and has continued apace since. As charismatic and forceful a politician as she undoubtedly was, we need to be wary of simply accepting the narrative that she was the sole agent of change in neo-liberal reform in the UK. That said, it has suited politicians of both left and right, in the incredibly narrow spectrum of British politics, to present Thatcher as the specific embodiment of the neo-liberal project in Britain. Conservatives have used this to contain the image of 'nastiness' (as Theresa May put it) in the persona of Thatcher and her governments. Blair, Brown and the New Labour contingent found Thatcher a 'straw woman'; by caricaturing neo-liberalism as Thatcherism on the one hand, and portraying a 'discredited' socialism on the other, they were able to define their own 
project as between these polar opposites (Cammack 2004; Nunn 2006). Put simply it suited politicians of all colours to associate Thatcherism with the divisive and unpopular elements of the class confrontation that she had presided over, while simultaneously pursuing an agenda designed to carry the wider political project forward. ${ }^{\mathrm{v}}$

\section{Five Legacies of Thatcherism in Britain}

\section{Short-term outcome: A Crisis in the neo-liberal project}

By the end of the 1980s and early years of the 1990s, the immediate outcome of first-phase neoliberalism was becoming apparent in Britain and elsewhere. ${ }^{\mathrm{vi}}$ This consisted of crisis tendencies in accumulation, social reproduction, ideological legitimacy and the supporting political alliance. In relation to accumulation, de-industrialisation was accompanied by the growth of low productivity services as well as the heights of finance. High and structural unemployment, low wages and low productivity in a low skill-equilibrium (see Error! Not a valid bookmark self-reference. and Figure 2) were symptoms of this. A crumbling transport and public and social infrastructure intensified by public spending cuts and privatisation contributed causally (Nunn 2006; Nunn 2007). It became commonplace to talk of Britain being 'in decline' (Gamble 1990; Hutton 1995; Coates 2000), and as the Major government of the early 1990s tried to distance itself from Thatcher's personal politics it struggled with the effects of the second Thatcher recession, a difficult fiscal position and a monetary and exchange rate crisis which ultimately led to ejection from the European Exchange Rate Mechanism.

Figure 1: Working Age* Unemployment (1971-2012)

\section{INSERT FIGURE ONE ABOUT HERE}

ONS (accessed 20-06-2013), Labour Market Statistics, LFS Time Series Data. Series: YBTI, YBTJ. Notes: Seasonally Adjusted. * Working age is 16-59/64.

Figure 2: Labour Productivity (1970-1991)

\section{INSERT FIGURE TWO ABOUT HERE}

ONS (accessed 20-06-2013), National Economic Accounts, Productivity: Output per-Filled Job, Time Series Data, Series: LNNP.

In relation to social reproduction, the effects of the two-nation strategy: of rising inequality and 'dropping out' and disengagement from the formal economy (worklessness, homelessness, drug misuse, informal economy, rising crime) meant that it was difficult for significant sections of the potential working class to reproduce their labour power (in day-to-day and inter-generational terms) in a way that was attractive to capital or that sustained existing communities. An occupational pyramid was replaced with an hour glass structure with those at the bottom in insecure and low-paid employment particularly in unskilled manual and even high-skilled service sector employment (Gallie 1998; Gallie and Paugam 2002; Smith and Middleton 2007; Shildrick et al. 2012).. This polarisation has been a noted feature of the UK labour market for some time (Goos and Manning 2003) but has recently increasingly been noted in Europe and internationally also (European commission 2011; Standing 2011).

Large sections of the potential workforce were completely excluded by the increased labour market discipline of the Thatcher era. Socially and spatially ${ }^{\text {vii }}$ concentrated pockets of what would become 
termed 'worklessness' emerged among disadvantaged social groups and in spatial communities affected by economic restructuring. This was all concentrated still further by the 'sorting' interaction between housing and labour markets as those who were less successful in the labour market were gradually concentrated in 'residual' public and social housing (Hills 2007: 86-111), urban ghettos and regions left behind by the 'switching' effects of Thatcher's first and second recessions and the deindustrialisation they spawned.

The roots of these problems in the Thatcherite two-nation class project are clear. Economic restructuring was driven forward by a combination of the capitalist strategies of technological innovation and offshoring and a series of consciously pursued policies of the Thatcher government including the famed 'cold bath' labour policies, opening up to international competition, market deregulation and privatisation; and legislation curtailing the power of organised labour (Gamble 1990; Overbeek and van der Pijl 1993). Reforms to disinvest in public housing, promote mortgage markets and to ideologically promote owner-occupation as the housing tenure of choice were also responsible.

The failure to implement a credible accumulation strategy and collapsing social reproduction clearly affected legitimacy among those directly affected - the second nation. However, by the early 1990s they also affected those sections of the working class targeted by Thatcher for inclusion in her first nation. The new property owners of the working class who bought their own homes, encouraged by the promotion of mortgage markets and state property sell offs (e.g. the Right to Buy) were suffering from negative equity and an increase in home repossessions (Nunn 2005: Ch3.).

Figure 3: Mortgage Arrears and Repossessions (1969-2009)

\section{INSERT FIGURE THREE ABOUT HERE}

ONS (2013), Social Trends, 41, Housing Data (Accessed 20-06-2013).

This also contributed to a collapsing political alliance. The terms of this were clear inside the Conservative Party that ultimately expelled Thatcher as its leader. It was evident also in the political miscalculation over the imposition of the Poll-Tax which was characteristic of the weakening hold of authoritarian populism (Jessop et al. 1990). Finally, it could be seen in the increasing resistance of public sector managers to the imposition of privatisation and elements of the new public management. Here the increasing successes of Labour led municipal authorities to resist privatisation through Compulsory Competitive Tendering (CCT) as they mastered the strategy of the in-house bid is illustrative. What all this added up to was a sense of crisis in the implementation of the neo-liberal project in the UK (Jessop et al. 1990: 98).

Figure 4: Crime and Recorded Crime Rate (1950-1997)

\section{INSERT FIGURE 4 ABOUT HERE}

Home Office (2004), Crime in England and Wales 2003/2004, Home Office Statistical Bulletin, London: Home Office (July).

\section{Long-term outcome one: New Labour and the transformation of mainstream party competition}

The weaknesses of Thatcherism did not go unrecognised at the time, by those that would be at the heart of the process of carrying on the neo-liberal project in Britain, albeit in a different way: 
"The limitations of Thatcherism are clear. The claims of an economic miracle have evaporated. Society is divided. The people are insecure. The public is once again ready to listen to notions associated with the left." (Blair 1994: 2).

New Labour would use this backdrop to generate a politics of legitimacy and consent for further neoliberal restructuring. They were acutely aware of three things: (1) the need for state intervention to promote innovation and competitiveness; (2) the problems generated by the extension of market discipline without the corresponding social and institutional infrastructure that could contain it; (3) and the need to broker legitimacy. But they tackled these problems in a way that took full advantage of the conjunctural class victory secured by Thatcherism, particularly the curtailment of the power of organised labour from the process of policy making and implementation. Once reinforced by the corresponding curtailment of the power of organised labour inside the Labour Party itself, this has had profound implications for the rather limited debate about, and extremely limited pressure for, a revised accumulation regime, that continues to be a problem for the UK economy.

It is tempting to think of the New Labour Project (NLP) as the construct of Tony Blair and Gordon Brown, with intellectual encouragement from the likes of Anthony Giddens (Cammack 2004; Nunn 2006; Jessop 2007; Nunn 2007). It is worth noting though that the Labour Party had been moving toward the central positions of the Third Way for several years prior to Tony Blair becoming leader in 1994. After the election defeat of 1987, the party instituted a 'Policy Review' process which resulted in ending its commitment to unilateral nuclear disarmament, strongly redistributive taxation and nationalisation (Labour Party, 1989). Before his death John Smith, then leader of the party, had established a Commission on Social Justice which resulted in the publication by the IPPR (1993) of Social Justice in a Changing World which elaborated a remarkably Third Way social, economic and welfare agenda. By the time the 1997 General Election approached Blair was able confirm confidently that the Party had adjusted itself to the economic 'realities' of Neo-liberalism:

"The key to New Labour economics is the recognition that Britain...[has] to compete in an increasingly international market place...Today's Labour Party, New Labour, is the political embodiment of the changed world - the new challenges, the new economics and the new politics" Tony Blair, speech to the Bundersverband des Deutschen Industrie Bonn, Germany, June 1996. (quoted in Hay and Rosamond 2002: 152).

The NLP recognised that the pursuit of competitiveness required more active state intervention; that this meant that more consensual relations were required with a whole cadre of public sector managers and the blunt hammer of CCT was replaced with Best Value and ultimately increased public sector investment. The NLP saw weaknesses in the physical and social infrastructure as a drag on competitiveness and recognised the need for a more skilled and productive workforce (Nunn 2006; Nunn 2007). The project sought to secure support for increased social investment in the context of neo-liberalism through 'corporate welfare' and channelling increased investment through the private sector in the Private Finance Initiative (PFI) and similar mechanisms (Whitfield 2001). Firms would be encouraged also to spend more on research and development, to innovate and be more productive and, through new Regional Development Agencies, were incentivised to form clusters. These strategies saw the structural unemployment created by Thatcher's 'cold bath' labour policies as unhelpful and set about the 'activation' of the unemployed and inactive through Active Labour Market Policies (ALMPs) and pay subsidies to overcome benefit dependency traps and support working families. This was all tied together with a political ideology that suggested the programme of reform was pragmatic rather than ideological, focused on national renewal for the benefit of all and based on a balance of rights and responsibilities. As Jessop (2007) has it, this was an attempt to shift 
from Thatcher's two-nation to a one nation approach, but noticeably without the reintegration of organised labour into the policy making process in any serious way. Indeed, organised labour was to be circumvented by the direct appeal to the neo-liberal individual and household through the electoral system and an obsession with media management. An illustrative example is the direct attempt to secure the continued material and political support of low paid families through the wage subsidies (in the form of tax credits) rather than by engaging organised labour and capital in a debate over wages and working conditions. The result was a rather shy, if real, form of backdoor redistribution that left the balance of power between capital and labour undisturbed.

\section{Long-term outcome two: The neo-liberal individual}

Thatcherism is widely associated with the possessive individualism of neo-liberal politics. Consumerism was the field in which identity could be affirmed and expressed outside of the shackles of class positions. Advancement in the hierarchy could be gained through the possession of material goods, starting with homes and moving through personal transport to consumer goods and clothing. Those promoting the transformation of the left to accept rather than reject this notion of the possessive and consumerist individual suggested that these were permanent and even welcome changes (Leadbeater 1988). Two sets of significant implications arose from this: the pursuit of consumerist aspiration through labour market success and New Labour's acceptance and manipulation of the idea of the citizen-consumer in public service reform.

The way in which the NLP confronted the labour market problems left over by Thatcherism (as above) is interesting and thoroughly revealing for the purposes of trying to understand Thatcherism's long-term outcomes. The NLP confronted useless long-term and structural unemployment through policies designed to 'activate' the unemployed and inactive. It worked to combat 'social exclusion' and promote the legitimacy of the new labour market competitiveness. It tried hard to draw in deprived social groups and spatially disadvantaged communities through very carefully targeted initiatives. For evidence one only need look at the evolution of Public Service Agreement targets focused on specific social groups and the proliferation of 'Area Based Initiatives'. But it did not seriously confront inequality, labour market polarisation or the insecurity faced at the bottom of the labour market. It recognised but did very little and possibly even accentuated the low-pay no-pay employment cycle by continuously working to activate a latent labour force rather than improve the working conditions and pay of those in the labour market. If a 'one nation' vision was to be realised it would be through the excluded transforming themselves - with state help - to resemble the included rather than by transforming the conditions that gave rise to inclusion/exclusion in the first place. The only conclusion to draw from this is that long-term inactivity and unemployment were seen as bad (for everyone, but including capitalists wanting to access a ready supply of cheap labour) while cyclical poverty, low pay and unemployment were less of a concern because they kept the labour force competitive: put simply they generated discipline on labour.

This process required the very clear attempt by New Labour (especially in its later period in office see (Nunn 2008; Nunn and Johnson 2008)) to drive down the concern with competitiveness and individual risk bearing to individuals and households. This is symbolised by the increasing political take-up of the idea of 'Social Mobility' (Nunn 2013). This is partially because it allows all of the mainstream parties to talk about concerns with social justice and the distribution of resources without actually focusing on original inequality (though this is nonsensical: one generation's inequality of outcome is the next generation's inequality of opportunity). It was also taken up as a legitimation of the aggressive pursuit of an individual politics of aspiration. 
Indeed, it is often argued by politicians - including now Cameron (The Telegraph 2013) - that one of the causes of labour market polarisation is not structural economic or political factors but the lack of aspiration among the working class themselves, both individually and for their children (Nunn 2012). As such, schools and educational providers are encouraged to promote aspirational behaviours amongst children. Those familiar with children's school reports in the UK will no doubt be fully aware of the efforts built into the fabric of the education system to inculcate this aspirational aptitude amongst children. Parents are cajoled to promote it at home (it is a quality assumed present in middle class and functional working class households but not dysfunctional ones). University lecturers are not immune either. A combination of consumerist (through the Key Information Sets (KIS) that are made available to prospective students to facilitate their 'choice') and institutional pressures (by managements wanting to improve $\mathrm{KIS}^{\mathrm{viii}}$ profiles and league table positions) are brought to bear to promote employability skills (for a review see Nunn et al. 2009) and aspirations not just for work, but for employment deemed to be of graduate standard.

This approach to labour market policy is only one part of the changed relationship between the state and the individual, which is shaped around the idea of the citizen as consumer. The continuation of Thatcherite objectives of privatisation (Marquand 2004: 118) while recognising the limitations of Thatcherism's disregard of public services was also a key characteristic of the NLP. New Labour borrowed from Thatcherism the idea of the citizen as individualised consumer of public services but took much more seriously the commitment to use the state as the defender of the public/consumer interest. As such, New Labour could distance itself from the by now unpopular image of Thatchersism as disinvesting in public services and promote the idea of reforming them to meet the needs of modern consumer culture. Again, just as in the labour market, Thatcherism had provided the role of breaking the coalitions of support for the social democratic compromise but not rearticulating governmental strategy of reconnecting to the change circumstances. Thus New Labour could simultaneously distance itself from the political image of Thatcherism while continuing to promote neo-liberal reform, in this case orienting public services to meet the needs of a consumerist and individualised citizenry, at the same time as opening up opportunities for stable revenue flows for capital in new forms of privatisation through partnership.

\section{Long-term outcome three: De-industrialisation and financial sector dependence}

One obvious and commonly cited outcome of Thatcherism is the twin process of de-industrialisation and increased reliance on the financial services sector, despite contemporary defences to the contrary (see Coates 1994: 285-289). However, de-industrialisation is also frequently seen as a continuation of pre-existing trends, some of which could be traced back to the end of World War 2 or even further to the gradual decline of British leadership of the international system at the end of the $19^{\text {th }}$ Century (Radice 1984; Gamble 1990: Ch1; Coates 1994). Indeed, crisis and decline were the backdrop to Thatcher's political and economic narrative. Certainly the appeal to monetarism - as sound money: a preference for capital as money rather than capital as production - was set in these terms (Gamble 1979; Gamble 2001). As with other aspects of the Thatcherite legacy though, the adoption of monetarism, the increased exposure to international competition and penetration of the UK economy by overseas capital and the decisive step back from industrial activism on the part of the state, all contributed to accelerating de-industrialisation and the rise of the financial sector.

The corollary to de-industrialisation was increased and broad-based dependence on finance. Others have dealt with the causes of the current crisis (Gamble 2009; Harvey 2010), but as Morgan (2009) notes, while the US sub-prime housing market ultimately acted as the trigger for the crisis, the same 
role could have been played by any one of a wide range of structural weaknesses that these industries promoted and exploited. What is worth noting here (e.g. see Figure 5 and Figure 6) is the popular dependence on financial products that has grown out of the declining share of overall economic growth taken by wages.

Figure 5: Proportion of overall output accounted for by salaries

\section{INSERT FIGURE ABOUT HERE}

Source: National Statistics Dataset NatPD, Compensation of Employees at Current Prices (DTWM), GDP at current prices (YBHA). Accessed 23-06-2013.

Figure 6: Net Household financial liabilities as a proportion of UK GDP

Insert Figure about here

Source: ONS Time series data: Net Household financial liabilities NNPP, GDP at current prices YBHA.

This dependence on financial products has to be seen as part of the emergence of the current crisis in four main ways. First, reliance on rising asset values fuelled by cheap credit, and the in-built and systemic demand for ever expanding credit from financial accumulation has been the basis of enduring if unstable legitimacy for those at the apex of the unstable accumulation regime, those able to realise equity to maintain personal consumption as well as those able to access property ownership for the first time (Hay and Wincott 2012: Ch7). Second, the widespread reliance on financial products is just one reason why politicians and regulators were so averse to regulating and constraining financial innovation and risky practices in the first place. As state provision of short and long-term social security has been scaled back, so households have not just covered immediate revenue gaps with loans, they have insured against financial problems with pensions, life insurance and various forms of income and payment protection insurance. Regulators and politicians were well aware that these financial products and the speculation attached to them required greater and more liquid markets to perform and that without this, the system could not continue to grow and those who were already embedded in it would potentially lose out. They also rationalised - see for instance the concept of financial inclusion promoted by New Labour and continued by the Coalition ${ }^{\text {ix }}$ - that increasing access to financial services for the poorest and most vulnerable was one way of combatting extreme poverty and promoting effective labour market activation. Third, the reliance on financial products, and debt fuelled asset markets (principally property) also gave the wider population an interest in collectively believing ${ }^{x}$ in the on going propensity of these markets to rise. Fourth, once the crisis hit, the widespread social exposure of the population to financial services meant that the government could feel justified in stepping-in with tax payers money on the reasonably genuine grounds that there was a widely shared and national interest in doing so. In the mainstream political debate following the 2007/8 financial collapse criticisms of the bailouts themselves have been notable by their absence; disappearing under the entirely questionable logic of austerity offered by the Coalition (Radice 2011; Morgan 2013). Widespread exposure to financialisation is at least partly to blame for the ease with which the Coalition is able to do this.

In both these respects; de-industrialisation and increased financial sector dependence, Thatcherism was central to securing the conditions in which successors could continue these trends. The shift of the norm toward owner occupation in property markets, made the continuation of the concern with managing inflation as opposed to managing demand and inflation a more obvious target for successive governments. The decisive victory secured in symbolically significant industries (e.g. 
Coal Mining) and the existing exposure of British capital to international competition meant that rolling back de-industrialisation was so much more difficult. The spatial and social effects of deindustrialisation meant that state support for further financialisation and 'financial inclusion' all the more easy to pursue and the loss of the industrial basis of organised labour has reduced the political pressure for a renewed and broader based accumulation strategy.

\section{Long-term outcome four: The fractured and unconscious working class}

If the Coalition Government began with controversy over its public spending cuts (Radice 2011), that has become more entrenched as the winners and losers from that process have become clear. Recently much attention has been paid to the myriad of changes to the Welfare system which include increased conditionality for the inactive and unemployed (e.g. the debates over forced work trials and benefit sanctions), increasing activation of lone parents, changes to the indexation of benefits to reduce their relative value over time, the introduction of the 'benefits cap' and the new penalties for recipients of housing benefit who are assessed as 'under-occupying' their properties (Weishaupt et al. 2014 Forthcoming). These policies are widely thought to be regressive and lead to greater poverty and inequality. Perhaps the most defining and long-lasting legacy of the Thatcher era, and unchallenged by New Labour in the intervening years, is that these policies, while divisive, retain a significant amount of public support.

For example, public opinion polling shows considerable support for current welfare reductions. Ipsos Mori (Hall 2012) show that $78 \%$ support benefit sanctions for jobseekers if they refuse work they are able to do, on the grounds (of the entirely rational and individualist(!) calculation) that they would be the same or worse off than they would be on benefits. The same poll showed that an even larger proportion (84\%) believe that greater conditionality needs extending to welfare recipients on sickness or illness related benefits. 62\% express support for capping the benefits of recipients with 'many' children and 57\% agree that housing benefit (which can be claimed while in low income employment) recipients should be forced to move if they live (and presumably work) in high cost areas. Further, longitudinal research for the British Social Attitudes survey shows a long-term trajectory of declining public support for welfare and increasing public support for personal over collective responsibility, even after Thatcherism. For example, in 2012 62\% thought that benefit levels were too high and discourage work, twice the proportion who thought the same in 1991 (NatCen 2012: welfare chapter). Further still, analysis of this data by Ipsos Mori shows progressively falling support for welfare between the generations, with those born after 1979 being the least supportive (Mori 2012).

There are feedback effects between the different long-term outcomes identified here. For example, as New Labour became progressively less generous toward welfare benefit recipients (see Nunn 2008), so too self-identified labour supporters moved away from support for welfare (NatCen 2010: Ch2). What this suggests is that there is a self-reinforcing link (no causal directions assumed here) between the party political transformation, the inculcation of the neo-liberal individual and the fracturing of the working class. Furthermore, the BSA evidence also suggests divergent views on welfare by occupational groups with professionals being less supportive than people in more routine occupations which we know are less secure (Gallie 1998; Gallie and Paugam 2002).

In interpreting this data two things are notable. The first is that New Labour's attempt to deal with Thatcherism's two nation problem was ultimately ineffective. In times of growth it may be easier to sustain a limited and superficial façade of inclusivity while leaving the economic structures of inequality and social structures of possessive and aspirational individualism unchallenged. In hard times of increased insecurity it is much harder to do so. Tensions and contradictions remain within the economic strategies of neo-liberalism - competitiveness etc - and attempts to embed it in a social and 
ideological structure that can sustain it. Secondly, polling across countries shows that support for welfare is no lower in Britain than in other countries in Europe and is considerably stronger than in the United States (Clark 2013). Other polling evidence, commissioned by the TUC, suggests that public opinion is very badly misinformed on the scale of public spending on welfare, and the level of welfare benefits for individual claimants, and that this is positively related to their likelihood of thinking welfare is too generous (TUC and YouGov 2013). Outside of the current divisive and misinformed public debate on welfare benefits per se, there is still considerable support for the role of government in supporting the least well off, ensuring opportunities for children and for providing a safety net. If Occupy, UK uncut, Left Unity, TUC Marches for the alternatives and opposition to university tuition fees, welfare cuts and the like are added to this a more complex picture of legitimacy and class consciousness emerges. In sum, this suggests that the fractured working class is still contestable as a political project.

\section{Conclusions}

It is argued here that caution should be exercised in extending too much agency to Thatcher as an agent of neo-liberal reform. Neo-liberal reform in Britain was pursued by both Conservative and Labour government's before Thatcher came to power and has been pursued since by both main parties, and arguably now the Liberal Democrats also.

Thatcherism is understood as part of a 'first-phase' in neo-liberal reform in the UK and is symbolically associated with first-phase/roll-back neo-liberalism in a wider international context. The significance of Thatcherism, as debated contemporaneously, turned on whether it could be seen as a decisive and potent political force transforming British capitalism and society or whether it was a rather more contingent, weak and contradictory political project. With the benefit of hindsight, the analysis of Thatcherism's outcomes offered here suggests that elements of both these interpretations have merit. Thatcherism, like first-phase neo-liberal strategies more broadly, was replete with weaknesses and contradictions. In particular it is suggested here that the absence of a coherent accumulation strategy and the effects of policy on political, social and ideological legitimacy led to a crisis in the neo-liberal project. The terms on which this crisis were addressed however, reflected the embedded shift that had taken place in political economy and politics in the UK. Thatcherism's primary long-term outcome was a decisive intervention in pre-existing class struggles to fundamentally weaken the working class and its institutions for political and economic representation, most notably organised labour inside and outside the Labour Party. New Labour's transformation into a fully neo-liberal political party, alongside on going attempts to develop the neo-liberal individual and the resulting fractured working class are all evidence of this transformation. Where Thatcherism's outcomes were much more limited and insipid was in the articulation of a revised accumulation regime, governmental strategy and social conditions which could sustain neo-liberalism.

But just as Thatcherism failed to put in place a hegemonic neo-liberal transition, from the perspective of the current conjuncture the New Labour second-phase attempt also appears to have foundered. The economic crisis of 2008 onwards and the translation of this into a political and social crisis is once again threatening a collapse of legitimacy. As Morgan (Morgan 2013) notes, the Coalition government is not so much tackling these weaknesses with its austerity and 'bleak optimism' as "kicking of the can" in the hope that organic solutions arise which further reinforce the weakening of the social obligations of the state. Crisis, as the discussion of both the emergence and transition from Thatcherism shows, is a time of opportunity for political change: one that the forces of the right are well accustomed to taking advantage of. The Conservative led coalition has been ready to exploit this 
opportunity and the ease with which this has been pursued is symbolic of the long-term implications of neo-liberal reform during and after Thatcherism traced here. Indeed, in the absence of effective left opposition, one of the major challenges to the new Conservatism of the Cameron government is from the right of his own party and the UK Independence Party.

In this context, what should the left do? The fundamental shift of politics outlined above suggests that the state may no longer be a credible target for left-advocacy. The state had much more potential as a zone of political struggle when there was a realistic proposition of national growth and significant redistribution of the benefits of that growth to improve the relative standard of living of the working class. In a world beset by a geo-political transition in the locus of growth eastwards this is less possible. Opposing the inexorable erosion of the welfare state in response to the competitive threat from the East seems unlikely to be successful. Further complexity is added by the environmental, ecological and resource effects of working to offset the effects of competition through transnational solidarity and equalising the standard of living of the global working class upwards. The quandary that this leaves for the left is substantial, but suggests that, even if it ever was credible, the pursuit of socialism while leaving the institutional forms and practices of capitalist social relations intact is no longer viable. Instead, radical new forms of economic, social and political organisation are required which acknowledge the unlikely nature of support for a genuine socialism through the existing party political process. The starting point is to continue to provide alternative explanations for, and debate about, the current crisis - in its social effects, not just technical accounts of financial market collapse - but to do so in ways that challenge the idea of the neo-liberal individual and the fractured working class consciousness identified above.

\section{References}

Blair, T. (1994). "Socialism." Fabian Pamphlet 565.

Boas, T. and J. Gans-Morse (2009). "Neoliberalism: From New Liberal Philosophy to Anti-Liberal Slogan." Studies in Comparative International Development (SCID) 44(2): 137-161.

Bruff, I. (2010). "Germany's Agenda 2010 reforms: Passive revolution at the crossroads." Capital \& Class 34(3): 409-428.

Cammack, P. (2002). Neoliberalism, the World Bank, and the new politics of development. Development Theory and Practice: Critical Perspectives. U. Gothai and M. Minogue. London, Palgrave.

Cammack, P. (2004). Giddens' Way with Words. The Third Way and Beyond: Criticisms, Futures and Alternatives. L. Martell, S. Hale and S. Leggett. Manchester, Manchester University Press.

Clark, T. (2013). "Britons favour state responsibilities over individualism, finds survey." The Guardian.

Coates, D. (1994). The Question of UK Decline: The Economy, State and Society. New York, Harvester Wheatsheaf.

Coates, D. (2000). Models of Capitalism: Growth and Stagnation in the Modern Era,. Cambridge, Polity Press.

Craig, D. and G. Cotterell (2007). "Periodising neoliberalism?" Policy \& Politics 35:3: 497-514.

European commission (2011). Employment and Social Developments in Europe 2011. Brussels, European Commission.

Gallie, D. (1998). Restructuring the Employment Relationship. Oxford, Oxford University Press.

Gallie, D. and S. Paugam (2002). Social Precarity and Social Integration: Eurobarometer 56.1. Brussels, European Commission.

Gamble, A. (1979). "The free economy and the strong state." Socialist register 16(16).

Gamble, A. (1988). The free economy and the strong state: the politics of Thatcherism. Basingstoke, Macmillan

Gamble, A. (1989). "The Politics of Thatcherism." Parliamentary Affairs 42(3): 350-361. 
Gamble, A. (1990). Britain in Decline: Economic Policy, Political Strategy and the British State. London, Macmillan.

Gamble, A. (2001). "Neo-Liberalism." Capital \& Class 25(3): 127-134.

Gamble, A. (2009). The spectre at the feast, Palgrave Macmillan Basingstoke.

Goos, M. and A. Manning (2003). Lousy and Lovely Jobs. London, London School of Economics: Centre for Economic Performance.

Hall, S. (1983). The Great Moving Right Show. The Politics of Thatcherism. S. Hall and M. Jacques. London, Lawrence and Wisehart.

Hall, S. (1985). "Authoritarian populism: a reply to Jessop et al." New Left Review 151: 115-124.

Hall, S. (2012). 21st Century Welfare: Seventy Years Since the Beveridge Report London, Ipsos Mori.

Hall, S. and M. Jaques, Eds. (1983). The Politics of Thatcherism. London, Laurence and Wisehart.

Harvey, D. (2005). A brief history of neoliberalism. Oxford, Oxford University Press.

Harvey, D. (2010). The enigma of capital: and the crises of capitalism. Oxford, Oxford Univ Press.

Hay, C. and B. Rosamond (2002). "Globalisation, European integration and the discursive construction of economic imperatives." Journal of European Public Policy 9(2 (April)).

Hay, C. and D. Wincott (2012). The Political Economy of European Welfare Capitalism, Palgrave Macmillan.

Hills, J. (2007). Ends and Means: The Future Roles of Social Housing in England: Centre for Analysis of Social Exclusion Report 34. London, London School of Economics.

Hutton, W. (1995). The State We're In. London, Vintage.

Jessop, B. (2003). From Thatcherism to New Labour. The Political Economy of European Employment. H. Overbeek. London, Routledge: 137-154.

Jessop, B. (2007). "New Labour or The Normalization of Neo-Liberalism?" British Politics 2(2): 282288.

Jessop, B., K. Bonnett, et al. (1990). "Farewell to Thatcherism? Neo- Liberalism and 'New Times'." New Left Review I(179): 81-102.

Jessop, B., K. Bonnett, et al. (1984). "Authoritarian populism, two nations, and Thatcherism." New Left Review 147: 32-60.

Jessop, B., K. Bonnett, et al. (1985). "Thatcherism and the politics of hegemony: A reply to Stuart Hall." New Left Review 153: 87-101.

Leadbeater, C. (1988). "Power to the person: New times: The changing face of politics in the 1990s." Marxism Today October: 14-19.

Marquand, D. (2004). Decline of the Public. Cambridge, Polity Press

Morgan, J. (2009). Global Economic Crisis: Causes and Solutions. Presentation to Sussex IPE Group. University of Sussex.

Morgan, J. (2013). "Optimism, pessimism and compression dynamics: the mis-shape of things to come?" Mimeo.

Mori, I. (2012). The Generations. London, Ipsos Mori.

NatCen (2010). British Social Attitudes Survey 26. London, NatCen.

NatCen (2012). British Social Attitudes Survey 29. London, NatCen.

Nunn, A. (2005). The Political Economy of Crisis and Global Governance: A thesis submitted to the University of Manchester for the degree of Doctor of Philosophy in the Faculty of Humanities. Manchester, University of Manchester.

Nunn, A. (2006). "What next for the New Labour Project after Blair?" State of Nature.

Nunn, A. (2007). "Competitiveness and the New Labour Project." Papers in the Politics of Global Competitiveness 8.

Nunn, A. (2008). "Restructuring the English Working Class for Global Competitiveness." Papers in the Politics of Global Competitiveness 9.

Nunn, A. (2012). "The Political Economy of Competitiveness and Social Mobility." British Politics.

Nunn, A. (2013). Social Mobility and Social Cohesion in European Countries. Strasbourg, Council of Europe. 
Nunn, A., T. Bickerstaffe, et al. (2010). Post-Code Selection? Employers' Use of Address-Based Information Shortcuts in Recruitment Decisions, DWP Research Report. Norwich, HMSO.

Nunn, A., T. Bickerstaffe, et al. (2009). The Employability Skills Project. Wath-upon-Dearne, UK Commission for Employment and Skills.

Nunn, A. and S. Johnson (2008). "Labouring and learning towards competitiveness: the future of local labour markets after Harker, Leitch and Freud." Local Economy 23(2): 122-137.

Overbeek, H. and K. van der Pijl (1993). Restructuring Capital and Restructuring Hegemony. Restructuring Hegemony in the Global Political Economy; The rise of transnational neoliberalism in the 1980s. H. Overbeek. London, Routledge.

Peck, J. and A. Tickell (2002). Neoliberalizing space: the free economy and the penal state:. Spaces of Neoliberalism: Urban Restructuring in North America and Western Europe. N. Brenner and N. Theodore. Oxford, Blackwell.

Polanyi, K. (1957). The great transformation : Karl Polanyi. Boston, Beacon Press.

Radice, H. (1984). "The national economy: a Keynesian myth?" Capital \& Class 22: 111-140.

Radice, H. (2011). "Cutting government deficits: Economic science or class war?" Capital \& Class 35(1): 125-137.

Sanderson, I. (2007). Worklessness and Deprived Neighbourhoods: A Review of Evidence, Report for the Neighbourhood Renewal Unit. London, DCLG.

Schwarz, B. (1987). "The Thatcher Years." The Socialist Register 23: 116-152.

Shildrick, T., R. MacDonald, et al. (2012). Poverty and Insecurity: Life in Low-pay, No-Pay Britain. Bristol, Policy Press.

Smith, N. and S. Middleton (2007). A review of poverty dynamics research in the UK. York, Joseph Rowntree Foundation.

Standing, G. (2011). The precariat: The new dangerous class. London, Hodder Arnold.

The Telegraph (2013). "David Cameron: We are building an 'aspiration nation'." (16 March).

TUC and YouGov (2013). Support for benefit cuts dependent on ignorance, TUC-commissioned poll finds. London TUC.

Weishaupt, T., H. Jørgensen, et al. (2014 Forthcoming). Delivering Activation: The Perpetual Reform of Public Employment Services in Europe. Labor Activation in a Time of High Unemployment: Encouraging Work while Preserving the Social Safety-Net. D. Besharov and D. Call. London and New York, Oxford University Press.

Whitfield, D. (2001). Public Services or Corporate Welfare: Re-thinking the nation state in the global economy. London, Pluto.

\footnotetext{
${ }^{i}$ E.g. Left Unity (http://leftunity.org/)

${ }^{\text {ii }}$ None of this is to suggest that other important legacies such as the politics of devolution, race and gender are not important.

iii Indeed Boas and Ganse-Morse (Boas and Gans-Morse 2009) comment that the term “... can mean virtually anything as long as it refers to normatively negative phenomena associated with free markets ..." (152) and "...neoliberalism has become a conceptual trash heap capable of accommodating multiple distasteful phenomena without much argument as to whether one or the other component really belongs" (156).

iv These strategies do not need to be understood as successive, as Peck and Tickell (2002) highlight. However, In Britain (in contrast to Germany for e.g. in the Agenda 2010 reforms (Bruff 2010)) they were largely - if not wholly - successive.

${ }^{\mathrm{v}}$ Neo-liberal political projects were not just attempted in Britain but in Chile and New Zealand before Britain, and in large parts of the developing world at the hands of the Bretton Woods Institutions concomitantly.
} 


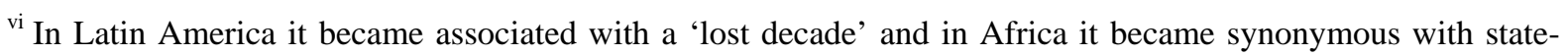
debt bondage, entrenched poverty and even state collapse, laying the grounds for a variety of political movements such as Juiblee, Drop-the-Debt and Make Poverty History.

${ }^{\text {vii }}$ For personal characteristics associated with social groups at disadvantage in the labour market see Sanderson (2007), for spatial characteristics of labour market disadvantage see Nunn et al. (2010).

viii Key Information Set data on which Universities are intended to be judged by prospective students: http://unistats.direct.gov.uk/.

ix See the work of the Financial Inclusion Taskforce: http://www.hmtreasury.gov.uk/fin_consumer_fininclusion.htm

${ }^{x}$ and acting on that belief - witness not only property speculation among a large proportion of households, either through buy-to-let or through regular home moves but also the cult of popular culture (e.g. the many and varied TV shows dedicated to benefiting and leveraging a constantly rising housing market). 